\title{
THE RELATIONSHIP OF ZONING TO TRAFFIC-GENERATORS
}

\author{
Allen Fonorofr ${ }^{*}$
}

Traffic like the weather is a very popular topic of conversation or profanity. But unlike the weather, steps are being taken to do something about it.

The problems that vehicular and pedestrian traffic create are among the most perplexing daily problems facing a community and its people. Technological advances in the automotive industry have made the automobile available to millions of people, and the number of car owners grows larger each year. Trucking has become a major industry competing with rail and air for the movement of goods and materials. The streets and highways are jammed with cars and trucks fighting to move from place to place. This is a common scene familiar to all urban communities.

The most frequent question asked is what can be done to alleviate the congestion of vehicles and people. Before an answer to this question is attempted, it is more important to know the causes of the congestion. Obviously it is not enough to say that motor vehicles cause traffic problems, since our modern society could not very long exist without these vehicles. Traffic problems exist because of the relationship between the streets and the use of lands abutting the streets. The solution to the problems created by the congestion of motor vehicles does not lie alone in the more efficient use of streets or movement of vehicles. Nor will the entire answer be found in off-street parking lots, off-street loading berths, or mass transportation. A recognition of the relationship between streets, traffic, and land use is essential before any solution can be attempted. Herein lies the job of the city planner.

This critical relationship is one of the most important factors that a planner will consider before proposing use districts and zoning regulations for a community. Although this statement may be accepted as a matter of fact, zoning regulations are, more often than not, taken for granted. Unfortunately very few people stop to consider the various elements that go into the planning and zoning of a community. The traffic-generating capacity of the many different uses of land and buildings is of primary importance in establishing the various zoning use districts. A more obvious example is the recent inclusion in many zoning ordinances of provisions requiring off-street parking spaces and off-street loading berths. The relative degree of traffic-generation has been the determining or influencing factor in the inclusion

* A.B. 1947, University of North Carolina; LL.B. 1949, Columbia University. Member of the New York and Ohio bars; City Planner in charge of zoning, City of Clevcland City Planning Commission, since 1951. Formerly with the New York City Planning Commission, 1950-1951, and the consulting firm of Harrison, Ballard and Allen assisting in the preparation of the "Plan for Rezoning the City of New York," I949-50. 
or exclusion of certain uses of land or buildings from the various use districts of a community: for example, the exclusion of high density apartments from one and two-family dwelling-house districts; the exclusion of commercial establishments from all residence districts; the exclusion of warehouses and manufacturing operations from retail districts; the exclusion of heavy industrial use from residence-industry districts; the exclusion of hospitals and other community facilities from one and two-family dwelling-house districts.

These examples indicate the basic and specific situations in which the problem is raised, and how important the traffic generating capacity of the use of land and buildings is to planning and zoning.

Our courts have dealt with hundreds of cases involving the practice of zoning. Have the courts, in dealing with zoning regulations, recognized and shown any understanding of the traffic-generating capacity problems so inherent in planning and zoning? That is the point of this article.

\section{The Purpose of Land Use Classification}

Zoning is the legal process by which a community is divided into zones or districts for the purpose of controlling the use of land and buildings, the size of buildings, and their location on a lot. Zoning regulations-use and bulk-vary as between different districts of a community since the character and function of the several districts differ. This exercise of the police power should be in accordance with a comprehensive land-use development plan embracing the entire community. Zoning is the legal means available to promote an orderly development of a community, or, as is more often the situation, an attempt to bring a semblance of order out of existing chaotic development.

The first comprehensive zoning ordinance in the United States was adopted by New York City in Igr6. Traffic generation was not absent from the minds of the framers and promoters of this adventure. It was apparent to them that the trucking serving the garment industry at that time had almost rendered valueless the existing specialty retail area. The Fifth Avenue Association exerted much pressure to keep the garment industry below $34^{\text {th }}$ Street. Thus one of the major inspirations for zoning New York City was to protect the city against the deterioration caused by misplaced uses and their resulting traffic. Since that time thousands of municipalities have adopted zoning regulations. The modern ordinances reflect the tremendous change in thinking by planners. New techniques of land development and new methods of control have evolved.

In the early days of zoning, vehicular traffic created very few problems, but it has grown to a point where today it dominates the thinking of city planners. This is seen in the greater emphasis on bulk regulations, provisions for off-street parking and loading, and the creation of new types of use districts.

It is almost impossible to talk about zoning without talking about traffic and transportation. Through zoning, a community may control the density of its pop- 
ulation, and the location of its various businesses, industries, parks, playgrounds, and other community facilities. Many standards and principles are employed in determining the proper methods of control. It is not difficult to see that one of the prime principles of planning and zoning is traffic-generation. Undoubtedly a combination of height and high density of the land, plus an active business operation on the land, will overcrowd adjacent streets. Under such circumstances, it is virtually impossible for people or goods to move from place to place.

Different types of land uses and the different height and bulk of buildings create definite kinds and amounts of traffic. It is important to spell this out carefully.

It has been firmly established that there is a close relationship between the use of land and buildings, including their height and bulk, and the streets which they abut. ${ }^{1}$ The streets and sidewalks will only accommodate a certain number of people and vehicles, depending of course on their physical capacity. Therefore the more intense the use of the land, the greater the height and bulk of the buildings, the more intense is the use of the streets. Thus it becomes clear that a limitation on building height and bulk and a selection of appropriate uses will proportionately reduce the congestion of people and vehicles on the streets. Naturally, traffic density will differ as to kind and amount with different types of neighborhoods. For example, the traffic picture is quite different between and within residential, commercial, and industrial districts.

The design and layout of the street system of a new community, to a large extent, fixes the character of the use of the lands fronting on the street. In new communities, a functional street pattern can reinforce the effectiveness of a zoning ordinance. A residentially zoned area can be better protected and preserved when the street layout functions to exclude through automobile and truck traffic. In the older and more developed communities, methods are constantly being sought which will lessen if not eliminate through traffic and truck traffic. ${ }^{2}$

The reason for this protection of the people and the preservation of the zoning classification is not, contrary to most of the earlier decisions, ${ }^{3}$ to preserve property values, but-more important-to protect the people living within the area against undue traffic hazards and to lessen the noise and confusion caused by cars and trucks.

${ }^{1}$ Lewis, Highway Traffic, III Regional SuRvey of New York and Its Environs 100-10I (1927); Robert B. Mitchell and Chester Rapkin, Urban Traffic: a Function of Land Use (INSTitute for Urban Land Use and Housing Studies, I954); Zoning and Traffic (Eno Foundation, 1952).

${ }^{2}$ Bagby, Protecting Good Neighborhoods From Through Traffic Decline, 8 Trapfic QuarterLx 4 ro422 (1954).

${ }^{3}$ Village of Western Springs v. Bernhagen, 326 Ill. 100, I56 N.E. 753 (1927) (the village zoning ordinance included most of the area in a single family use district; the court upheld the ordinance as a reasonable exercise of the police power since the erection of a filling station on one of the village streets would depreciate residential property values); Bianchi v. Comm'rs of Public Buildings, 279 Mass. 136, 18I N.E. I20 (1932); Koch v. City of Toledo, 37 F.2d 336 (6th Cir. 1930); Morris v. East Cleveland, 22 Ohio N.P. (N.s.) 549, 31 Ohio Dec. 98, r97 (x920); De Lano v. City of Tulsa, 26 F.2d 640 (8th Cir. 1928). 
The importance of a street system-its design and location-to the well-being of a community cannot be over-emphasized. Depending upon the traffic-generating capacity of the land uses that abut the streets, a street system, if properly located and designed, will permit people and goods to move freely from one point to another. On the other hand, where a street system, designed and laid out for horse-andcarriage traffic, is now lined with skyscraper office buildings or large manufacturing establishments or high bulk apartment buildings, such a system cannot function properly. The congestion of people and motor vehicles almost throttles movement. Functioning as they do as channels of transportation and communication, the streets are indispensable to the operation of a community. It is, therefore, the trafficgenerating capacity of the abutting land uses that will determine the success or failure of a street system and the efficient operation of a community. That is why it is so important that use classifications be made to minimize congestion and thus to protect the safety of the people and their physical as well as monetary investment in a community. In order to avoid unsafe and uneconomic congestion of vehicles, a scheme must be developed that will balance the use of land and buildings, their height and bulk, and the capacity of the streets and highways.

Different types of commercial buildings, for example, put varying loads on the land and generate varying degrees of traffic. To illustrate this statement, $\mathrm{Mr}$. Ernest P. Goodrich ${ }^{4}$ pointed out that the streets of a community have definite limits, and it is therefore important to limit the land load in order to avoid congestion. Mr. Goodrich referred to the studies of the Regional Survey of New York that revealed the average quantity of traffic created by certain types of uses:

0.2 vehicle per day per family for deliveries, including building material, groceries, and so forth;

0.85 vehicle per family, according to the automobile registration statistics given in the

United States Statistical Abstract, I928;

therefore, $0.2+(0.85 \times 2)=$ I.9 vehicles per family is the total traffic per family per day; 6.0 vehicles per day per foot of a roo-foot lot in industrial sections;

r.O vehicles per day per foot of frontage in business districts;

0.5 vehicle per day per foot of frontage in loft building districts;

4.0 vehicles per day per foot of frontage in theater districts;

0.5 vehicle per day per foot of frontage per story for department stores; or

r.o vehicle per day per 165 square feet of floor space for department stozes;

x.o vehicle per day per foot of frontage for hotels (transients only).

As a part of its monograph on Highway Traffic, ${ }^{5}$ the Committee on Regional Plan of New York and Its Environs undertook a careful study of the relation between vehicular traffic and the height and bulk of buildings in the borough of Manhattan. That study showed that the existing streets could not possibly accommodate

\footnotetext{
'Goodrich, Controlling the Load on Land Through Zoning, 155 The Ansals r66, I68, Pt. 2 (May, I93I).

III Regional Survey of New York and Its Environs, op. cit. supra note I, Appendix $C$, at I43I 49.
} 
the buildings that might be erected under the permissible height and area regulations. It was pointed out that building heights had to be kept below the legal limit in order to have a functioning street system. This conclusion was reached in 1927 and is more true today. In the past twenty-seven years the zoning and building errors have been compounded. It does not take a planner or traffic engineer to realize the complexity of the problem and the almost hopeless situation that faces New York City.

Because of the interrelationship of land use, building height and bulk, and the street system, it is important to recognize that a change in land use will to some degree affect the character and volume of traffic. The reverse is also true: a change in the character and volume of traffic will affect the way in which land and buildings are used.

\section{Zoning Regulations As Applied to Traffic}

It has already been pointed out that zoning provides a very basic and important tool to deal with the traffic-generating capacity of the various uses of land and buildings. Zoning regulations have much to do with the physical development of a community. Zoning promotes a certain stability by providing locations for various uses within well-planned and functional use districts. This control, potential or real, over use and bulk allows a community to take steps toward the relief, and wherever possible, the elimination or prevention of vehicular and pedestrian congestion. The possibilities that zoning has offered are no longer dreams since its constitutionality has been so well established. ${ }^{6}$

Through zoning it is possible to put into execution a plan for a community which may and should include a street plan that will serve the various zoning districts. Relying upon the stabilizing influence of zoning, a street plan can provide for the efficient and convenient movement of people and goods. Fast-moving through traffic will be separated from slow-moving local traffic. Some phases of modern business require a certain amount of concentration. However, efficient operation does not require all the floor space to be confined to a series of skyscrapers. Thus trafficgenerating uses will be dispersed within well-defined economic units that will utilize existing streets with a minimum of congestion.

Zoning regulations can slow down and, in some situations, stop the deterioration of a neighborhood resulting from the overloading of existing narrow streets that cannot be improved to increase the traffic flow. Some of the results of careful planning and zoning are the opening up of the streets for safe and efficient movement of vehicular and pedestrian traffic; the reduction and perhaps elimination of accidents; and the removal of through-traffic from local streets.

These results are generally accomplished by specific use and bulk provisions in a zoning ordinance. As for use regulations, the following have a direct bearing on traffic and tend to alleviate the problems brought on by congestion:

${ }^{\circ}$ Village of Euclid v. Ambler Realty Co., 272 U.S. 365 (1926). 
r. Mapping of the zoning use districts. This permits the orderly growth and development of a community within districts preserved for specific usesresidential, commercial and retail, and industrial.

2. Classification of uses to be permitted in the various use districts. Trafficgenerators are so located as to do the least harm to the community. Incompatible uses are separated and permitted to locate with other similar uses where the street system is more adequate.

3. Provisions for the elimination of non-conforming uses. In addition to the nuisances created by these uses which do not conform in character to the other uses in the district, non-conforming uses create traffic conditions inimicable to the surrounding area.

4. Requirements for off-street parking. The taking of vehicles off the street removes these obstacles to traffic movement.

5. Requirements for off-street loading and unloading. Similarly, the removal of trucks from the curb will permit the entire pavement of a street to be used for through traffic.

6. Provisions for corner sight clearance. By prohibiting for a certain distance from the curb the obstruction of corners with structures, trees, hedges, and the like, the intersections are kept visually open to permit a safer and faster movement of vehicles and pedestrians.

These are perhaps the most important, although not all, of the zoning use regulations that have a direct effect on traffic.

There are many bulk controls found in zoning regulations that are directly related to minimizing the problems created by the traffic-generating capacity of the use of land and buildings. Among the most important are the following:

r. Regulation of building bulk and height. The overcrowding of the land with building and the resultant overcrowding of the streets is avoided by such controls.

2. Regulations limiting the density of population. This type of control is extremely significant. By limiting the number of familes that may dwell within a particular area, pedestrian traffic is reduced and possible congestion is avoided. Furthermore, the number of vehicles-buses, trolleys, delivery trucks, and automobiles-needed to serve such an area is proportionately reduced.

3. Provisions requiring front, rear, and side yards. Such requirements may provide adequate space for the parking of vehicles off the street.

The use and bulk regulations enumerated above will be discussed in more detail as they are applied to specific situations in another part of this article.

The early discussions of zoning and zoning law laid great stress on the protection of residential areas and the preservation of property values. Whether or not 
this emphasis is correct is not the concern of this article. However, the desire to preserve the residential areas from the invasion of commercial and industrial uses found fulfillment in comprehensive zoning. The home owner or tenant was concerned not only with the potential physical nuisances associated with business and industry, but also with the additional traffic these uses would bring onto his street, thereby increasing the danger to his children and disrupting his peace and quiet.

At this point it would be well to consider the traffic element as it is applied to the formation of the various zoning use districts and the uses that are permitted to occupy the land. The discussion will be limted to the following situations:

r. The allocation of land for the various uses that operate within a community.

2. The exclusion of certain uses from residence districts.

3. The selection of certain types of uses in residence-industry districts.

4. The exclusion of certain uses from local retail, general retail, and light industrial districts.

5. The separation of incompatible land uses.

I. Mapping the Zoning Districts. One of the most important steps in planning a community is the allocation of land for the many different types of uses of land and buildings that will operate within a community. The planner must attempt to estimate the future needs of the community and allow sufficient land area for expansion. He must also try to select the best physical location for the several zoning use districts. The relationship of one use district to another, and the relationship of each type of use district to the physical features of the land-waterways, highways, rail lines, varying topography-are important considerations. The element of traffic. generation is present in all these relationships, and will become more apparent as the discussion continues.

Before beginning the discussion of the exclusion of uses from the various use districts, the basic reasons underlying the classification of the use of land and buildings should be mentioned. First, similar uses are naturally grouped together. Included in this grouping are those uses that require similar conditions. For example, places for the care of the sick are permitted with low-bulk, low-density dwellings; factories and distributing establishments are permitted with warehouses. Second, each use district is designed for a basic type of land use-residences in residence districts, business in retail districts, etc. However, certain additional facilities and services are needed to complete the picture. Thus fire and police stations and other community facilities are permitted to locate near residences. Third, the remaining basic factor involving use classifications is the separation and segregation of incompatible uses. One of the most important factors of incompatibility is traffic generation.

2. Uses Excluded from Residence Districts. The inclusion or exclusion of certain uses from any district is based upon more than one standard or principle. How- 
ever, one of the basic principles is the traffic-generating capacity of the various uses of the land and buildings.

As for residence districts, the most common situation is the exclusion of apartment buildings from single and two-family use districts. Among the reasons for this attempt at exclusiveness is the protection of property values. This vague phrase has been repeated hundreds of times in justification of the establishment of singlefamily districts. Realistically, one of the basic considerations for this exclusion is to limit the traffic-pedestrian and vehicular-that would be brought into the district by apartment buildings.

The same basic reasoning is involved in the exclusion of business enterprises from residence districts. The argument most usually advanced to keep hospitals, schools, and other community facilities out of residence districts is the trafficgenerating capacity of these uses. Because there are more compelling reasons from a planning and social point of view for the inclusion of such uses within residence districts, provisions are included in zoning regulations to minimize the bad effects of additional traffic by requiring off-street parking and loading.

Furthermore, residence districts should be so zoned and designed, wherever possible, as to eliminate the necessity of crossing major heavy traffic streets to reach any community facility, thus increasing the safety of the community.

3. Uses Permitted in Residence-Industry Districts. A residence-industry district is mapped in certain areas of a community adjoining low-density residence districts. This type of use district is designed for those industrial or manufacturing uses that are free of nuisances and will harmonize with the adjoining residence district. It is therefore essential that the uses permitted to operate within this district will not, among other things, generate such traffic as will destroy the neighboring residential amenities and the usefulness of the residence-industry district itself. Examples of such uses are laboratories, such as the Johnson and Johnson laboratory in New Jersey and the B. F. Goodrich laboratory in Ohio, and the manufacture of watches and optical and medical goods. Additional protection is achieved through requirements for off-street parking and loading, a limitation upon the hours that trucking may be used, requirements for landscaping, and the like.

4. Uses Excluded from Other Districts. The techniques of zoning retail or commercial districts have changed considerably since $19 \mathrm{~g} 60^{7}$ First, the ribbon development of business uses along major thoroughfares has been replaced by the cluster development of business uses into new districts designed to meet the needs of the community. Underlying these new developments and the selection of uses permitted within the districts has been the element of traffic-generation.

Local retail districts are mapped in such locations that will efficiently serve the adjoining residence districts and minimize the possibilities of traffic congestion. The permitted uses include those which are needed to serve the everyday needs of

\footnotetext{
${ }^{7}$ Pollard, Outline of the Law of Zoning in the United States, I55 THE ANnals 15, Pt. 2 (May, I93I).
} 
the neighborhood and thus encourage pedestrian rather than vehicular traffic. Thus traffic-generation is kept at a minimum by controlling the density and type of use.

In the great majority of our cities a greater amount of land than is needed is zoned for retail or commercial business. Economic waste has resulted because of spotty, unplanned development. This in turn has retarded the development of other land uses in the areas so erroneously set aside for retail business. The scattered businesses have attracted traffic into areas which in most cases cannot cope with it. And again it is the unwanted and unnecessary traffic-generator that adds to the possible deterioration of part of a community.

On the other hand, well-planned, well-zoned retail districts are designed to function and are located in such a way as to do the least damage to the surrounding neighborhood and its streets. The permitted uses are carefully selected to exclude enterprises that have no relation to retail business but would merely add turmoil to the streets. Warehousing, trucking terminals, and other non-retail traffic-generators should be excluded. This, incidentally, is not the case in New York City; warehousing and wholesaling are permitted in retail districts.

The element of traffic-generation could not be more obvious than it is in the downtown or central business districts of our large cities. The tremendous bulk and density of use have caused great hardships on the merchants and the municipal authorities. Planning and zoning came too latel Today, wherever the opportunity is present, the effects of traffic-generation are the dominant consideration in the planning and zoning of central business districts. Under a carefully drawn plan building height and bulk would be limited.

Thus it is apparent that the element of traffic is of primary importance in the planning and zoning of every variety of retail or commercial use district. The proper location of a commercial establishment, be it the corner drugstore or the repair garage, is influenced by its traffic-generating capacity.

Before leaving the discussion of retail and commercial districts, one more example is worth mentioning. The consultants who prepared "The Plan For Rezoning the City of New York" created a restricted commercial-residence district. This district was designed to serve a particular portion of Madison Avenue. The commercial uses are restricted to a floor area ratio of 3.5 while the residential uses may have a floor area ratio of ro.o. Uses such as banks, art galleries, and small office buildings are permitted. Such a proposal for streets like Madison Avenue would do much to reduce the density and bulk along the Avenue and also reduce pedestrian and vehicular activity.

The field of industrial zoning is beginning to undergo a tremendous change. The conventional list of permitted or prohibited uses is recognized today as unscientific and rather arbitrary. Some cities, notably Chicago, have undertaken the development of a system of performance standards based upon the actual measurement of the nuisances produced. An integral part of such a system is adequate relief from the nuisances caused by traffic. 
Under the traditional method of industrial zoning, industries are segregated according to their potential undefined nuisance capacity. Light industrial districts exclude the heavy trucking of heavy industry. Some of the newer zoning regulations also include requirements for off-street parking and loading as another step in alleviating traffic congestion.

5. Separation of Incompatible Land Uses. The last situation to be discussed is the segregation of incompatible land uses. One reason for such segregation is to remove those uses which cannot be "good neighbors" to the other land uses in the neighborhood. The problems of non-conforming uses and methods for their elimination are the subject of another article. It is enough for the purposes of this article to note again that one of the primary reasons and justifications for the elimination of non-conforming uses found in residence districts is the traffic generated by them. The elimination of these uses will also eliminate a hazard to the people of the community.

An attempt has been made here to point up the importance of the relationship between zoning and traffic-generation and to show how the elements of traffic fit into the planning and zoning of a community.

\section{Judicial Decisions}

Almost from the day the police power was first used to zone a community, the courts have had to decide upon the validity of zoning. Since the traffic-generating capacity of the use of land and buildings is such an important consideration, it would not be unreasonable to expect to find this important element reflected in judicial opinions. But that has not been the case! Except in the most obvious situations, as will be shown, the courts have either been unaware of this important element of land use regulation, or have taken it so for granted that it has been ignored in the decisions. The paragraphs that follow contain cases in which the elements of traffic are recognized and used as the basis for judicial opinions.

I. Gasoline Filling Stations. There has been a great deal of case law with respect to the regulation of gasoline filling stations. Most of these cases find their way to the courts via a zoning board of appeals decision denying an applicant permission to erect such a use. Yet out of all the case law very few decisions consider the traffic-generating capacity of filling stations. Two cases that did consider this element were found in New Jersey and Connecticut.

In the New Jersey case, ${ }^{8}$ the City of Englewood refused to grant a permit for the erection of a filling station on Engle Street, and the Board of Adjustment refused to recommend to the governing body of the city a variance from the provisions of the zoning ordinance. The case came before the New Jersey Supreme Court on a writ of certiorari.

The land was located in a "Restricted Business Area" in which gasoline service stations were prohibited. The plaintiff claimed that the ordinance was unreasonable and unconstitutional in so limiting the use of its premises.

\footnotetext{
${ }^{8}$ Citizens National Bank of Englewood v. City of Englewood, r28 N.J.L. I47, 24 A.2d 819 (I942).
} 
In dismissing the writ, the court pointed out that the New Jersey statutes ${ }^{0}$ provided that zoning regulations permitted by the constitution "shall be in accordance with a comprehensive plan and designed for one or more of the following purposes: To lessen congestion in the streets; secure safety from fire, panic and other dangers; promote health, morals or the general welfare; provide adequate light and air; prevent the overcrowding of land or buildings; avoid undue concentration of population."

The court found that Engle Street was one of the major thoroughfares of the city; that in the vicinity of the premises in question the land use was partly residential and partly business and civic in character; that the street was heavily traveled; that drivers entering and leaving driveways had difficulty joining the traffic on the street; and that within the immediate area there was located a post office, a church, and two large schools.

The court said that the buildings in the immediate vicinity attracted large numbers of pedestrians and that the erection of a filling station would create a danger to these pedestrians. Considering the nature of the buildings in the area and the danger to the pedestrian traffic attracted to the area, the provision of the zoning ordinance was held to be reasonable.

The Connecticut case ${ }^{10}$ involved an appeal from the judgment of the Court of Common Pleas, Hartford County, reversing the judgment of the board of zoning appeals in refusing to grant a certificate of approval for the location of a gasoline filling station. The Board was appealing the action of the lower court.

The evidence showed that the premises in question were located at the intersection of Woodford Avenue, a main thoroughfare, and Woodland Street. Woodford Avenue narrowed about 250 feet east of the property and formed a traffic bottleneck. South and east of the premises there were residential areas including a housing project. Woodford Avenue was used extensively by the residents in this area. The court found that school children customarily passed the location in question on foot, on bicycles, or in buses; that on the north side of the avenue, opposite the land in question, was a parking lot used by a nearby industrial business accommodating several hundred vehicles; that the avenue was lined with parked cars; and that the traffic was heavy and created substantial congestion, especially during rush hours.

The street intersecting withWoodford Avenue, Woodland Street, was in a Residence " $\mathrm{B}$ " Zone which adjoined the premises. The lot itself was in an industrial zone in which gasoline filling stations were permitted. However, the Connecticut law required a certificate of approval for the location of such uses.

The lower court decided that the zoning board was wrong in refusing to grant a certificate of approval. The Connecticut Supreme Court of Errors reversed the

\footnotetext{
${ }^{0}$ N.J. STat. ANN. $\$ 40: 55$-I (1953).

${ }^{10}$ Mrowka v. Board of Zoning Appeals of Town of Plainville, 134 Conn. 149, 153-154, 55 A.2d 909, 9II, 9 I2 (I947).
} 
judgment of the lower court and remanded the case with a direction to dismiss the appeal.

After deciding that the lower court had jurisdiction in the matter, the Supreme Court went on to say that in determining the proper location for a filling station the conditions of the area existing at the time the application is made must be considered. The question to be decided, the court pointed out, was whether the proposed use would unduly "imperil the safety of the public." To answer this question, the court said consideration must be given to the other uses in the vicinity. The area, although in an industrial zone, was not built up and this fact had a bearing on the correctness of the board's finding. The court said that the fact "that a use for a gasoline station would not create a greater traffic hazard than use for other permissible purposes in such a zone is hardly a matter of which a court can take judicial notice; indeed, by requiring a certificate of approval for the location of a gasoline station and not for the other uses enumerated, the legislature has in effect established the contrary of the basis on which the court proceeded."

The court held that the findings showing the number of vehicles and pedestrians, especially children, passing the location in question, the traffic congestion, and the use of the neighboring properties made it clear that the zoning board could reasonably deny the application for a certificate of approval.

2. Other Cases. A recent case in Wisconsin upheld the exclusion of a private school from a residence district. In State ex rel. Wisconsin Lutheran High School Conference $v$. Sinar, ${ }^{10^{a}}$ the zoning ordinance of Wauwatosa permitted in a Residence A District public schools and private elementary schools. A Lutheran church was not permitted to erect a high school in this district. The court found the classification valid and non-discriminatory. In its decision the court cited the arguments against permitting such a use in a Residence District:

Appellants have made it abundantly clear that respondent's projected school has many features which seriously impair the social and economic benefits to the entire community which the zoning law is designed to preserve and promote. It will add to the congestion of the surrounding streets.

The cases that follow involve a change in zoning from residential to industrial, a junk yard, an asphalt mixing plant, a trucking terminal, a warehouse, a business use in a residence zone, and a garage.

In Parson $v$. Town of Wethersfield, ${ }^{11}$ the zoning ordinance of the town was amended so that property belonging to one Griswold was rezoned from a residence district to a light industrial district. Plaintiff sought a declaratory judgment determining the validity of the zoning change. The lower court held for the town, and plaintiff appealed.

Among the grounds for the appeal was that there was no substantial change in the neighborhood since the adoption of the zoning regulations.

\footnotetext{
${ }^{102} 267$ Wis. 9I, — 65 N.W.2d 43, 46 (I954).
}

${ }^{21}$ I35 Conn. 24, 31, 60 A.2d 77x, 774 (1948). 
In upholding the decision of the lower court and the action of the town zoning commission, the Supreme Court of Errors held that the construction and opening of a major highway was an important factor to be considered in reclassifying the area from residence to industry. A master plan had been worked out by an expert planner recommending the particular change. The zoning commission said, "This change of zoning is made to provide for the most appropriate use of this land in view of its location between the Silas Deane Highway and the New Haven Railroad, and to encourage the development of desirable types of light industry within the Town of Wethersfield." The court said that the evidence fully justified a finding that the land was suitable for industrial use because of its location, its physical surroundings, and its relationship to the rest of the town.

In Miller $v$. Zoning Board of Appeals of City of Hartford, ${ }^{12}$ plaintiff was the owner of a parcel of property 509 feet by 765 feet. A portion of the front was zoned for business. The rear of the property was in an industrial zone. Plaintiff applied for a certificate of approval to use the property as a motor vehicles sales lot and a motor vehicle junk yard. The zoning board of appeals denied the permit and was reversed by the lower court.

The general statutes of Connecticut ${ }^{13}$ required, as a prerequisite to the issuance by the commissioner of motor vehicles of a license to operate a motor vehicle junk yard, a certificate of approval of the location from certain local officials. The statute provided that the designated authority in considering an application for a certificate should "take into account the nature and development of the surrounding property; the proximity of churches, schools, hospitals, public buildings, or other places of public gathering; the sufficiency in number of other such yards or businesses in the vicinity; the health, safety and general welfare of the public; and the suitability of the applicant to establish, maintain or operate such yard or business and to receive a license therefore. ..."

The evidence showed that Waterfield Avenue, on which the property abuts, was one of the main arteries of the city; that the neighborhood was largely residential; that several apartment buildings housed a large number of families, including many children; and that there were two schools in the vicinity.

The Supreme Court held that the mere fact that the property in question was in an industrial zone did not entitle the plaintiff to a certificate of approval. To locate a junk yard in close proximity to property used for residential purposes might reasonably be considered something approaching a public nuisance.

Although the court did not specify what it meant by a public nuisance, it is clear from its language that the dangers of the traffic that would be created by this use were paramount in the court's decision.

In Mitchell Land Co. v. Planning and Zoning Board of Appeals of Township of Greenwich and Bell v. Planning and Zoning Board of Appeals of Township of

\footnotetext{
${ }_{12}^{13} 8$ Conn. 610, 87 A.2d 808 (1952).

${ }^{23}$ ConN. Gen. Stat. $\$ \$ 4655-4656$ (Supp. I953).
} 
Greenwich, ${ }^{14}$ the land company owned land in a general business zone and proposed to construct and operate an asphalt mixing plant. The premises were serviced by barges and by trucks using the surrounding streets.

Most of the neighboring lands were devoted to industrial uses except the land on South Water Street (across from the company's property) which was improved with single and double homes.

In March, I952, the company applied for a special exception to construct and operate the plant, and after public hearing it was denied because a large number of trucks would service the property each day and create hazardous traffic conditions on South Water Street. Also the unloading of sand and gravel would create dirt and dust in the neighborhood. An appeal was taken by the Company and in July, 1952, while the appeal was pending, the Company filed an application for rehearing. After the rehearing the Board granted an exception. From that action, the residential property owners filed an appeal. The lower court heard both appeals and dismissed each of them. From these judgments both parties appealed.

The Supreme Court of Errors of Connecticut first held that the rehearing by the Board was proper and legal because (I) a change of conditions had occurred since the prior decisions; and (2) other considerations materially affecting the subject matter had intervened and no vested rights had arisen.

The plans for the asphalt plant had been changed to meet the objections raised at the first hearing. The entrance and exit for trucks had been relocated to reduce the danger of traffic. A large portion of the property was earmarked for truck off-street parking and steps were to be taken to reduce and eliminate dirt and dust. Thus circumstances existed which justified a rehearing by the Board. The exception was granted with the following conditions:

On rehearing it appeared that a large industrial use has been permitted on adjoining property since our decision in this case; that Water Street is $5^{\circ}$ feet in width; and that the plan has been redesigned to provide entrance and exit ways for trucks and for onthe-lot parking while waiting for loads. . . . These new facts and safeguards . . . have persuaded us to grant the appeal, and in doing so we impose the following conditions and safeguards:

I. Materials shall be wetted down from time to time to prevent dust.

2. The ground surface of the entire lot shall be covered with oil or asphalt.

3. The plant shall not be operated on a night shift.

4. All trucks employed in the business shall park on the premises.

5. Sand and gravel shall be stored in bins.

6. The plant shall at no time be operated unless its dust and smoke elimination devices are functioning.

7. That there shall be evergreen planting to screen the plant from South Water Street.

8. That the plant be relocated on the lot so that the entrance shall be where the exit is shown on the plot plan which will eliminate crossing the flow of traffic by trucks proceeding south on Water Street.

9. The parking shall be located in the northeast section of the lot.

14 140 Conn. 527, 一, 102 A.2d 316, 318 n. I (1953). 
The granting of the exception was upheld by the Court on the grounds cited by the Board.

The case involving a trucking terminal is Borough of West Caldwell v. Zell. ${ }^{15}$ Defendant was convicted in the municipal court for a violation of the zoning ordinance-conducting a truck terminal in a business district. He was loading and unloading truck cargoes with the use of large tractors and trailers. This was defined as an industrial use by the zoning ordinance. Defendant contended that this was a permitted use in the business district because the ordinance did permit a public gararge for purposes of auto repair and it also allowed certain types of storage and warehousing. It was contended that an amendment to the Borough ordinance permitted operation of a bus garage for interstate buses in the business district. It was the operation of a truck terminal and transfer depot that was brought in question in this case.

In upholding the judgment of the lower court, the Superior Court held,

This ordinance seeks to prevent the operation of a truck terminal and transfer point along the main business thoroughfare. Such an ordinance is a manifestation of the underlying goal of reducing heavy traffic and is well within the police power of the municipality. The ordinance is not arbitrary but is based on a reasonable classification which permits in a business district local trucking and storage incidental to local business but does not permit the operation of a truck terminal and transfer depot incidental to interstate movements.

Another New Jersey case is Saraydar v. Board of Comm'rs of City of Newark..$^{10}$ This involved a certiorari proceeding by plaintiff to review a resolution of the Board denying his application for a permit to use his premises in a residence district for a warehouse. Warehouses were not permitted in residence districts.

The court upheld the decision of the Board of Commissioners as legal and reasonable since such a use would employ fifteen trucks in its operation.

An interesting case in point is Kent v. Zoning Board of Review of Town of Barrington. ${ }^{17}$ This case came to the Supreme Court of Rhode Island on a petition for certiorari. The plaintiff owned twenty acres of farm land with 800 feet of frontage in a Residence " $\mathrm{B}$ " district. No businesses were permitted by the town zoning ordinance in such a district, except that products grown on the premises might be sold on the premises. Plaintiff applied for a variance in order to sell ice cream, dairy products, and produce, but intended to import the milk, cream, and other ingredients from another source. The planning commission opposed the variance on grounds of health and traffic congestion, and on the basis of the potential residential character of the area. The Board denied the petition for a variance for the following reasons:

r. Plaintiff intended to conduct a business on a large scale involving quantity

${ }^{25} 22$ N.J.Super. 188, x9x-192, 91 A.2d 763, 765 (Essex County Ct., 1952).

${ }^{16}$ I3I N.J.L. 290, 36 A.2d 289 (I944).

${ }^{17} 63$ A.2d 736 (R.I. x949). 
production. Such an operation to be successful would attract large numbers of highway travelers which would increase the hazards of traffic.

2. The area, although not completely developed, was suitable for development of attractive residential buildings free of business influence.

3. The proposed business would injure the neighboring property and cause a depreciation of values in the general area.

The court found that there was no abuse of discretion on this question on the part of the Board. The denial of the variance was reasonable and plaintiff's rights were not infringed.

In Fortuna v. Zoning Board of Adjustment of City of Manchester, ${ }^{18}$ a bill in equity was brought to review the decision of the zoning board granting to the Manchester Buick Company a building permit to erect an addition to an existing legal non-conforming garage. The court held, among other things, that the proposed addition would be beneficial to the public interest and that the existing traffic congestion on the two streets on which the Buick Company was located would be reduced with the proposed addition.

3. Off-Street Parking. Although over two-hundred communities have enacted some type of off-street parking regulations, the courts have not been given much opportunity to pass upon such legislation. An excellent case recognizing the necessity of providing space for parking is Town of Islip v. Summers Coal and Lumber Co.; ${ }^{19}$ this case involved a requirement for a front yard in a business district. The court quoted from the monograph, "Buildings: Their Uses and Spaces About Them," Volume VI, page 136, of the Regional Survey of New York and Its Environs:

When we come to consider the need of adequate space about stores for purposes of access and parking of vehicles we will find that what are wanted are wider streets and deeper lots rather than increased frontage. But the really important questions are the distribution of the store frontage throughout the community and the preservation of adequate open space about the business buildings. ... In many suburban store districts there is ample space in the aggregate, but ... not properly distributed so as to give satisfactory means of access, space for loading and unloading, room for parking without interference of through traffic, and sufficient light and ventilation. ...

The court went on to say:

A wise public policy may require the owners of new buildings in business districts under proper conditions to set their buildings back from the street in order to enable their business to function without congesting the streets.

In Ronda Realty Corp. $v$. Lawton, ${ }^{20}$ the realty corporation applied to Chicago's Building Commissioner for a permit to remodel an apartment building which would increase the capacity from twenty-one to fifty-three apartments. Space for 18 cars was

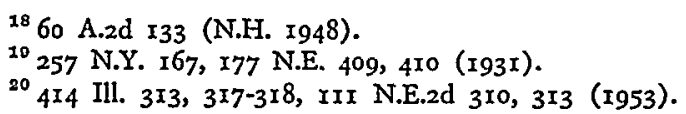


said to be available. A permit was issued and several tenants appealed to the zoning board. The question before the zoning board and before the court was a section of the Chicago zoning ordinance which required one off-street parking space for every three dwelling units in an apartment house. Since eighteen parking spaces would be required, the board revoked the permit because that number of parking spaces could not possibly be provided on the premises. The lower court found the ordinance discriminatory, depriving the corporation of equal protection. On appeal, the Illinois Supreme Court upheld the lower court's decision that that section of the zoning ordinance was an unlawful classification:

The evils to be remedied on crowded city streets are well known, but we do not see that the singling out of apartment buildings from the other types of buildings embraced by the ordinance is reasonably related to the elimination of those evils. Appellants urge that the classification is not discriminatory because it applies to all apartment buildings equally and because it is apartment buildings, more than any other type structure permitted, which contribute the most to street congestion caused by parked automobiles. We see neither a fair nor reasonable basis for such a classification nor its reasonable relation to the object and purpose of the ordinance. The street congestion problems created by boarding or rooming houses, hotels, and the like, are not essentially different from those caused by apartment buildings. All are similarly situated in their relation to the problems of congestion that are caused by parking cars in the street, and all contribute proportionately to the evil sought to be remedied. Indeed, we think it not unreasonable to say that the scope and nature of the congestion may be greater in the case of large rooming houses and hotels than in the case of apartment houses.

Although there has been a paucity of judicial language and consideration of the importance of the traffic-generating capacity of the uses of land and buildings, those courts that have spoken show a real respect for the subject and the problems created. It would be difficult to attempt to give any one reason for the lack of judicial opinion here. Corporation counsels, city attorneys, solicitors, and private practitioners would do well to consult the planner in the preparation of a brief involving planning and zoning. Only such cooperation will put before the courts all the reasons and thinking that go into planning and zoning a community, and this would in turn be reflected in the opinions. 